Cahiers de recherches médiévales

Journal of medieval studies

L'héritage de Chrétien de Troyes

\title{
Post-Chrétien Verse Romance
}

The Manuscript Context

\section{Keith Busby}

\section{(2) OpenEdition \\ Journals}

Electronic version

URL: https://journals.openedition.org/crm/2646

DOI: $10.4000 / \mathrm{crm} .2646$

ISSN: 1955-2424

Publisher

Honoré Champion

\section{Printed version}

Date of publication: 15 December 2007

Number of pages: 11-24

ISSN: $1272-9752$

Electronic reference

Keith Busby, "Post-Chrétien Verse Romance", Cahiers de recherches médiévales [Online], 14 | 2007,

Online since 15 December 2010, connection on 15 December 2022. URL: http://

journals.openedition.org/crm/2646; DOI: https://doi.org/10.4000/crm.2646 


\title{
酮RM
}

\section{Post-Chrétien Verse Romance : The Manuscript Context ${ }^{1}$}

The manuscripts in which the post-Chrétien (« epigonal») verse romances are preserved can speak volumes about their transmission and reception. In some cases, these are intimately bound up with the works of the master, although the intertextuality of the whole corpus of verse romance transcends the codicological context. I shall review here selected manuscripts in which some epigonal romances have been transmitted and what they can tell us about ways in which these texts were read in the Middle Ages. The romances in question are :

\author{
Renaut de Bâgé (Beaujeu), Le bel inconnu \\ Paien de Maisières, La mule sans frein \\ Le chevalier à l'épée \\ Raoul de Houdenc, Meraugis de Portlesguez. \\ Raoul (de Houdenc ?), La vengeance Raguidel \\ L'âtre périlleux \\ Guillaume le Clerc, Fergus \\ Hunbaut \\ Yder \\ Floriant et Florete \\ Le chevalier aux deux épées \\ Girard d'Amiens, Escanor \\ Claris et Laris \\ Jehan, Les merveilles de Rigomer
}

Compared with Chrétien's romances, themselves only preserved in half-adozen copies on average (but fifteen plus fragments of Perceval), these works are mainly codicological unica, with only Meraugis de Portlesguez, La vengeance Raguidel, L'âtre périlleux, and Fergus surviving in more than one complete exemplar. The tradition can therefore not be said to be rich, confirming Beate Schmolke-Hasselmann's contention that the first audiences of Arthurian verse romance were small select ones of afficcionados, ${ }^{2}$ a situation which persisted into the later $13^{\text {th }}$ and $14^{\text {th }}$ centuries, the period of manufacture of most of the manuscripts. The existence of Middle English and Middle Dutch adaptations of French Arthurian verse romances, including those of Chrétien himself, also surely

\footnotetext{
${ }^{1}$ This article draws on Chapter 5, pt. II, «Epigonal Arthurian Romance and its Manuscripts », of my Codex and Context : Reading Old French Verse Narrative in its Manuscript Context, vol. I, Amsterdam : Rodopi, 2002, p. 405-37, where I also discuss manuscripts omitted here for reasons of space.

${ }^{2}$ Beate Schmolke-Hasselmann, Der arthurische Versroman von Chrestien bis Froissart : zur Geschichte einer Gattuing, Tübingen, Niemeyer, 1980, p. 178-248.
}

Cahiers de Recherches Médiévales, 14, 2007 
reflects wider distribution and the bilingual cultural contexts in England and the Low Countries.

A number of codices include texts by both master and epigones. ${ }^{3}$ One of the best-known manuscripts of Arthurian verse romance is Chantilly, Musée Condé 472 $\left(\mathrm{s} .13^{\mathrm{ex}}\right.$ ), which contains the following romances :

Jehan, Les merveilles de Rigomer, fol. 1ra-55v

L'âtre périlleux, fol. $57 \mathrm{r}-77 \mathrm{v}$

Chrétien, Erec et Enide, fol. 78r-99v

Guillaume le Clerc, Fergus, fol. 100r-122r

Hunbaut, fol. 122r-133v

Renaut de Bâgé, Le bel inconnu, fol. 134r-153v $+153^{\text {bis }} \mathrm{r}$

Raoul (de Houdenc ?), La vengeance Raguidel, fol. 154r-173v

Chrétien, Yvain, fol. 174r-195v

Chrétien, Lancelot, fol. 196r-213v

Perlesvaus in prose (breaks off towards the end of Branch VIII), fol. 214r-243v

Le roman de Renart (Branches II, IV, Va, VI, VII and XV), fol. 244r-260r

I have argued elsewhere that the missing text of some of the romances suggests that Chantilly 472 is in a pre-final state and that its current order is most likely what the compiler intended. ${ }^{4}$ Of all manuscripts containing post-Chrétien verse romance, Chantilly 472 is the one to have received most critical attention, mainly from Lori Walters, who believes that it is a "Gauvain cycle ». ${ }^{5}$ There is much to be said for this view, which also takes into account the presence of the Perlesvaus and branches of the Roman de Renart (the latter as an animal avatar of Gauvain), but I wish here to take a slightly different, complementary, approach.

Chantilly 472 discards any idea of the order of composition of the romances, opening in a chronological reversal with one of the latest examples of the genre, which it transforms into a foundational text set in Ireland and the Celtic wellspring of Arthurian romance. By ordering the individual romances as he does, the planner of Chantilly 472 knowingly subverts what was in his time a perception that Chrétien was the founder of the genre. There is sufficient textual and intertextual evidence to argue forcefully that this is not simply a commonplace of modern literary histories. Les merveilles de Rigomer has become the matrix from which the other romances emerge in an inverted translatio studii that moves from West to East rather than vice-versa, enabling the matière de Bretagne to flourish in the British Isles and in France. The absence of Cligès with its Greek context underlines the popular origins of Arthurian romance.

\footnotetext{
${ }^{3}$ For the Chrétien manuscripts, including those with epigonal romances, see Les manuscrits de Chrétien de Troyes/The Manuscripts of Chrétien de Troyes, ed. K. Busby, T. Nixon, A. Stones, and L. Walters, 2 vols., Amsterdam, Rodopi, 1993.

${ }^{4}$ Codex and Context, I, p. 406-09.

5 L. Walters, "The Formation of a Gauvain Cycle in Chantilly, Manuscript 472 », Neophilologus, 78, 1994, p. 29-43.
} 
The damsel's challenge to Arthur and his knights at the beginning of the Merveilles (11. 75-84) ${ }^{6}$ is a catalyst for all of the adventures in all of the romances in the codex. Chantilly 472 is thus a manuscript of recreantise, a theme central to Erec et Enide, Yvain, and La vengeance Raguidel. It can also therefore be seen as an exploration of the way in which alternative heroes attempt to deal with this issue and restore the collective reputation of Arthur's court. The near-universal presence of Gauvain provides the articulation by means of which this exploration is carried out within the boundaries of the codex : the dual quests of Lancelot and Gauvain in the Merveilles; the fulfilment of the "Bon Chevalier» of L'âtre périlleux; the introduction of a new generation in the form of Erec, son of Lac; the elaboration of a «new Perceval» in Fergus; the clear counterpoint of Gauvain and the eponymous hero in Hunbaut ; the use of the filial double in Le bel inconnu; the complementarity of Gauvain and Yder in La vengeance Raguidel; the companionship of Gauvain and Yvain in Yvain; the parallel quest for Guenièvre in Lancelot; the Grail quests of Gauvain and Lancelot and the fundamental superiority of the Grail knight in Perlesvaus; and, finally, the potential of the "animal Gauvain» in Le roman de Renart.

The compiler of Chantilly 472 understood how Jehan composed Les merveilles de Rigomer and how he identified material suitable for inclusion in the narrative. The high incidence of themes and motifs common to the Merveilles and to the other romances stems precisely from his knowledge of Jehan's sources. In a sense, this takes one of the basic compositional procedures of epigonal romance to a new level. As authors of post-Chrétien verse romance take delight in quoting, reworking, and alluding to the foundational texts in the expectation that their expert audience would join in the game, so the compiler of Chantilly 472 alerts the users of the manuscript to his intertextual play.

Chrétien's Cligés is not included in Chantilly 472, but a Greek knight of the same name occurs in the Merveilles, in an episode featuring a perilous cemetery ( li astres maleis»). This episode (11. $9103 \mathrm{ff}$.) is then "troped» in the codex by the inclusion of L'âtre périlleux as the following text and by an episode in the Perlesvaus; the trope was in fact the source materia for the Merveilles. In the cemetery, Cligés finds an empty tomb, said to be destined for him (11. 9233-36), a reminiscence of Chrétien's Lancelot ${ }^{7}$ (also in Chantilly 472). And in the chapel pertaining to the cemetery, he finds the corpse in which a lance-point is still embedded (1l. 9281 ff.); when he removes it, the corpse comes to life and reproaches him for so doing; finally, Cligés kills the knight again by reinserting the lance-point. Jehan has taken this motif from La vengeance Raguidel and has transformed it from a major narrative device in the source romance into a subsidiary one in his own work.

Jehan assembles the section dealing with Gauvain's imprisonment and his subsequent liberation by Lorie (11. 10583 ff.) in a deft example of inventio from episodes and motifs from other romances in Chantilly 472. Hunbaut, La vengeance Raguidel, and Le bel inconnu make much of Gauvain's amorous past, and Lorie's freeing of him to participate in the tournament is derived from another episode in

\footnotetext{
${ }^{6}$ Ed. W. Foerster, 2 vols., Dresden, Gesellschaft für romanische Literatur, 1908-1915.

${ }^{7}$ Ed. W. Foerster, Halle, Niemeyer, 1899, 11. 1841-1966.
} 
Lancelot (11. $5378 \mathrm{ff}$.). Since both the Merveilles and the codex are predicated on a Lancelot-Gauvain contrast, the former's fathering of a child on the daughter of the King of Desmond (11. 4581-86) may be a narrative ploy to ensure a future rival for Guinglain in Le bel inconnu. In the Quintefeuille episode of the Merveilles, Jehan draws on two of Chrétien's romances in Chantilly 472: the inheritance dispute (ll. $15937 \mathrm{ff}$.) is modelled on the quarrel between the sisters in Yvain (1l. $4703 \mathrm{ff}$.), ${ }^{8}$ and the adventure with the robber knights (11. 16347-443) is reminiscent of events in Erec et Enide (11. 2795 ff.). ${ }^{9}$

There are other instances of intertextual dialogue which add to the richness of Chantilly 472 as a codex. The compiler of the manuscript did not write the romances, but he fully understood the complex connections between them, and not simply between the Merveilles and the other texts. The evolution of the postChrétien romances over just less than a century is a situation in which each subsequent text can draw on an ever-growing corpus of earlier ones. La vengeance Raguidel, for example, also seems to have provided material for both L'atre périlleux and Hunbaut, and a fuller study of Chantilly 472 would explore the consequences of this relationship within the structure of the manuscript. ${ }^{10}$ In another instance, the opening of Fergus " tropes " the white stag episode from Erec et Enide (the romance which precedes it) as it begins to rewrite and supplant the absent Perceval. ${ }^{11}$

If the Merveilles suggests one means of approach to the codex and its contents as an Arthurian intertext, a central episode of L'âtre périlleux may indicate another. Gauvain meets three maidens lamenting the death of . . Gauvain; with them is a vallet whose eyes were put out by the same three knights who are said to have killed and dismembered Arthur's nephew before they absconded with the corpse and limbs (11. 456 ff.). ${ }^{12}$ The exaggerated rumour of Gauvain's death divides the Arthurian world into two camps, the one rejoicing, the other lamenting. This division reflects the ambiguous presentation of Gauvain in the $12^{\text {th }}$ and $13^{\text {th }}$ centuries and invites readers of the romance and the manuscript to reflect on the potential of the character. Gauvain spends most of L'âtre périlleux as "cil sans nom" as he searches for his murderers and his own identity, just as the compiler of Chantilly 472 explores Gauvain in the various romances of the codex. The dismembered Gauvain of L'âtre périlleux is restored at the end of the romance, just as the various constituent leaves, limbs, and branches of the codex are conjoined in a rich portrait of the figure.

Nottingham, UL, Mi. LM. 6 (s. $13^{\text {ex. }}$ ) is a somewhat broader-ranging collection than Chantilly 472, containing Le roman de Troie, Ille et Galeron by Gautier d'Arras, Le roman de Silence by Heldris de Cornuaille, part of Le roman

\footnotetext{
${ }^{8}$ Ed. W. Foerster, Halle, Niemeyer, 1887.

${ }^{9}$ Ed. W. Foerster, Halle, Niemeyer, 1890.

${ }^{10}$ See my "Hunbaut and the Art of Medieval French Romance», in Conjunctures : Medieval Studies in Honor of Douglas Kelly, ed. K. Busby and N. J. Lacy, Amsterdam, Rodopi, 1994, p. $49-68$.

${ }^{11}$ On Fergus and Perceval, see Roel Zemel, "The New and the Old Perceval: Guillaume's

Fergus and Chrétien's Conte du Graal », BBIAS/BBSIA, 46, 1994, p. 324-42.

${ }^{12}$ L'âtre périlleux, ed. Brian Woledge, Paris, Champion, 1935.
} 
d'Alexandre, La chanson d'Aspremont, La vengeance Raguidel, and a number of fabliaux. It is the unique manuscript of Le roman de Silence and many of the fabliaux of Gautier le Leu. It is possible that this manuscript was made for Béatrix de Gavre on the occasion of her marriage to Guy IX de Laval (present-day department of Ille-et-Vilaine) in 1286 or shortly thereafter. ${ }^{13}$

The codex opens with Le roman de Troie (fol. 1ra-156rb), anchoring all texts that follow in a cultural tradition beginning with the Greeks. In other manuscripts, it is often followed by Le roman d'Eneas and/or Wace's Brut in a westward movement of translatio studii et imperii, precisely the movement that Chantilly 472 appears to put into reverse. While the sequence in Mi. LM. 6 is not a straightforward chronological and geographical one, it shows a concern with demonstrating the political and cultural unity of Europe and the unity of its narrative subject-matter, $L e$ roman de Troie representing the easternmost part of the terra cognita of the manuscript. The inclusion of Ille et Galeron (fol. 157ra-187vb) takes on particular significance in the light of its probable first owner, Béatrix de Laval, for Gautier d'Arras dedicates Ille et Galeron (11. 1-134, 6591-92ad.) to another Béatrix, Béatrix de Bourgogne, Empress of Germany, and also relates the death of Conan IV of Britanny (11. 4213 ff.). ${ }^{14}$ It would seem likely that the compiler of Mi. LM. 6 chose Ille et Galeron because of its association with a Béatrix and with Britanny. The importance of its hero's ethnic identity is not to be underestimated : Ille is a Breton, and his prominent role and investiture as Emperor of Rome would not only have flattered the Breton nobility at the end of the $12^{\text {th }}$ century, but also the house of Laval at the end of the $13^{\text {th }}{ }^{15}$ Ille et Galeron is apposite company for Le roman de Silence and La vengeance Raguidel, while Ille's investiture restores the Roman element missing in the absent Eneas.

None of the gender-oriented studies of Le roman de Silence (fol. 188ra$243 \mathrm{vb}$ ) have taken real account either of the question of ownership or of the manner in which the other contents of the codex might throw light on this particular romance. The opening sequence to Mi. LM. 6 is strongly female in its emphasis: the vigorous portraits of women in Le roman de Troie; the dedication of Ille et Galeron to Béatrix de Bourgogne, and the general praise of women in the prologue; the admirable presentation of Galeron and Ganor; the very subject-matter of Le roman de Silence and the emergence of the female voice.

The conjoining of Ille et Galeron and Le roman de Silence is basically achieved through issues of disguise, silence, and the repression of the female voice. The very nurturing of Silence, of course, is at once symbolic of all three; her subsequent disguise as a jongleur represents a first step in her self-liberation, although the persistent gender mutation results in the advances made to her by Eufeme. In Ille et Galeron, Galeron disguises herself as a man so as to gain admittance to the injured Ille's bedchamber; Galeron's selfless act of taking the veil after the birth of her two children by Ille is a form of female silence, self-imposed

\footnotetext{
${ }^{13}$ See Lewis Thorpe, ed., Le roman de Silence, A Thirteenth-Century Arthurian Verse Romance, Cambridge, Heffer, 1972, p. 10-12.

${ }^{14}$ Ed. Yves Lefèvre, Paris, Champion, 1988.

${ }^{15}$ Nor should it be forgotten that the river Ille flowed through the Laval domains.
} 
when compared with the forced repression of Silence's true voice, and an act that provides a solution rather than creating a problem.

Although it is not an Arthurian romance, Ille et Galeron does belong to a kind of matière de Bretagne; the subject of Le roman de Silence is clearly Arthurian, but its relationship to the post-Chrétien tradition is tenuous. For example, Ille kills the Greek knights, Gadifer and Eumenidus, thus demonstrating once more the valour of the Bretons, and that true power now lies in France, and Britanny in particular, not Greece or Rome: "c'ainc puis le tans le roi Artu / ne fu si fiers encontres fais " (1l. 2806-07). A further link to the wider Arthurian tradition is provided by the appearance in both romances of a character named Cador. In the first romance, he is a faithless Breton ally of Ille's treacherous cousin, Hoel, and is killed by Ille; in the second romance, he is the Count of Cornwall, father of Silence, situating the action of the romance in the context of Geoffrey's Historia Regum Britannice and Wace's Brut, where Cador plays an active role. In a romance concerned with inheritance and marriage, the choice of Cador as a father for Silence has peculiar resonances. In the Brut, Cador had been Guenièvre's foster-father prior to her marriage to Arthur, and Wace remarks that the couple was unable to produce an heir (11. 9641-58) ${ }^{16}$ Silence therefore represents a second attempt by Cador at nurturing that is likely to remain fruitless unless Silence proves able to cast off the yoke of masculinity. If read in the light of Arthur's death in the Brut, moreover, Silence's lineage is even more distinguished, as the kingdom is entrusted by Arthur to his cousin, Constantine of Cornwall, son of Cador (11. 13291-98).

In the rebellion against Ebains in Le roman de Silence, the Count of Chester "contrefait roi Alixandre» (1. 5518). The text of Le roman d'Alexandre which follows (fol. 244va-303va) is the long or ' $\mathrm{B}$ ' redaction of Le fuerre de Gadres with the extended version of Gadifer's exploits. ${ }^{17}$ In Ille et Galeron, Ille had killed Emenidus and Gadifer during his defense of Rome (11. 3025-36, 2809-13). The structure of Mi. LM. 6 required the inclusion of Le roman de Troie and Le roman d'Alexandre, but stressing the Celtic supremacy in both Ille et Galeron and Le Roman de Silence makes it quite clear that the era of Greek dominance in world history is over for good. The central position of Le roman d'Alexandre between Le roman de Silence and the next text in the manuscript, La chanson d'Aspremont, is further consolidated by the following passage : «Quar ains mius ne feri Costentins de Bretagne, / Ne cil de Durendal, qui fu niés Carlemaine, / Com fait Emenidus qui mal talent engraigne» (p. 127, 11. 13-17).

La chanson d'Aspremont (fol. 244va-303vb) relates Charlemagne's reassertion of his authority over Calabria, recently invaded by the Saracen king, Agolant, and his son, Aumont. The link between Le roman d'Alexandre and La chanson d'Aspremont is underscored early in the latter when Agolant's messenger announces to Charles :

\footnotetext{
${ }^{16}$ Wace, Le roman de Brut, ed. Ivor Arnold, 2 vols., Paris :, SATF, 1938-1940.

${ }^{17}$ Li romans d'Alixandre par Lambert li Tors et Alexandre de Bernay, ed. Heinrich Michelant, Tübingen, Bibliothek des litterarischen Vereins in Stuttgart, 1846, p. 93, 1. 1-211, 1. 13 ; text also in vol. V of The Medieval French Roman d'Alexandre, ed. F. B. Agard, Princeton/Paris, Princeton Univ. Press, 1942.
} 


\author{
«Rois Agolans i vient o son barnage; \\ Querre vos vient et par mer et par nage. \\ Quanqu'Alixandres conquist en son eage \\ Violt il avoir; cho est son iretage ; \\ Car il doit estre del soverain linage ». (11. 456-60) $)^{18}$
}

Charlemagne's victory over Agolant thus represents further confirmation of the superiority of the modern West over the ancient East, while Roland's conquest of Durendal from Agolant's son, Aumont, is a symbolic extension of the same notion. The significance of this kind of incidental reference, usually taken as the expression of a simple comparative topos, is on the contrary deserving of full intertextual consideration within the parameters of the codex and sometimes without.

The intermediary between manuscript and performance is the jongleur, whose integrative function is made quite clear in the description of one of Roland's battle companions :

[...] Et un dansel qui Graelens ot non.

Né de Bretagne, parent fu Salemon;

Deduitor Karle, estoit de sa maison

Et l'ot nori petitet valeton;

Ne gissoit mais se en sa cambre non.

So siel n'a home mels vïelast un son,

$\mathrm{Ne}$ mels desist un bon ver de cançon.

Icestui fist le premier lai breton. (11. 9482-89)

This short passage is quite extraordinary in both its codicological and literary-historical ramifications. Graelent is also, of course, the hero of an anonymous Breton lai, a genre said to be «founded» by his namesake, the entertainer of Charlemagne and companion of Roland. His ethnicity also relates him to Ille et Galeron, whose hero is the son of Eliduc, the protagonist of one of Marie de France's Breton lais. His kinship with Solomon further links him to the biblical tradition of wisdom and its medieval elaborations. Graelent integrates in his person roman antique, roman and lai breton, and chanson de geste, and through his activity as jongleur, he shares a profession with Silence and her mentors, whose repertoire includes Breton lais such as Gueron and Mabon (11. 2762, 2765).

The figure of the jongleur thus acts as bridge to La vengeance Raguidel (fol. 304ra-335vb), which is in turn followed (fol. 336ra-345vb) by the fabliaux of Gautier le Leu. If the Vengeance belongs essentially to the matière de Bretagne, it is also partly defined by the tone of some of its episodes and their affinity with fabliautradition. As examples, one only needs to mention the episode of the faithless Ydain (11. 4482-857) and that of the ill-fitting mantle (11. 3906-73). ${ }^{19}$ Gautier's poems all

\footnotetext{
${ }^{18}$ La chanson d'Aspremont, ed. Louis Brandin, 2 vols., Paris, Champion, 1919-1924. Mi. LM. 6 is the base manuscript for Brandin's edition.

19 Raoul (de Houdenc ?), Sämtliche Werke. II : La vengeance de Raguidel, ed. Mathias Friedwagner, Halle, Niemeyer, 1909 ; see also idem, «Die Vengeance Raguidel nach der
} 
explore, like the Ydain and mantle episodes, the lubricity of women and their fickleness; the foolish peasant and dim-witted knight of Le fol vilain and Le sot chevalier respectively invite comparison with Arthur's knights in general and Gauvain in particular.

Comparing the corpus of manuscripts that preserve a particular romance is another method of showing the variety of manuscript contexts. Of the five manuscripts of Raoul de Houdenc's Meraugis de Portlesguez, I shall look at only three, since Turin, BN, L IV 33 dates from the $15^{\text {th }}$ century and was severely damaged in the 1904 fire, and the fragment in the Archives Départementales du Var is too small to have much to tell us. Berlin, Staatsbibl., Gall. Qu. 48 is composite manuscript of the late $13^{\text {th }}$ century, made up of three manuscripts containing two chansons de geste - Auberi le bourguignon (fol. 1-143), Fierabras (fol. 158-90)and fragments of Meraugis de Portlesguez and Raoul's Le roman des eles (fol. 14457). Since Le roman des eles starts where Meraugis finishes, in the same hand on fol. $154 \mathrm{vb}$, this may have been an ouvres complètes of Raoul de Houdenc, which could in its original form also have included Le songe d'Enfer, the Dit (Le borjois borjon), and possibly La vengeance Raguidel. There are examples of author manuscripts or entire sections of manuscripts devoted to the work of a single author (the so-called Annonay fragments of Chrétien de Troyes or the Harley manuscript of Marie de France's Lais and Fables, for example) which constitute an invitation to read them together as works of the same poet. ${ }^{20}$

Vienna, ÖNB 2599 is a single-item codex $(20 \mathrm{~cm} \times 28.5 \mathrm{~cm}[14 \mathrm{~cm} \times 20.5$ $\mathrm{cm}$ ], in two columns of forty lines), dating from the end of the $13^{\text {th }}$ or the beginning of the $14^{\text {th }}$ century; it is quite lavishly illustrated and may come from the Louvre library. ${ }^{21}$ Among the epigonal romances it is unique, the only comparably illustrated manuscript being $\mathrm{BnF}$, fr. 1433, which pairs L'âtre périlleux with Chrétien's Yvain. ÖNB 2599 is the only manuscript of Meraugis to preserve the prologue (11. 1-32), ${ }^{22}$

Middleton-Handschrift», Zeitschrift für romanische Philologie, 39, 1918, p. 584-610, also printed separately (Halle, Niemeyer, 1918); The Vengeance has recently been re-edited by Gilles Roussineau, Geneva, Droz, 2004.

${ }^{20}$ See my «Le roman des eles as Guide to the sens of Meraugis de Portlesguez », in The Spirit of the Court: Selected Proceedings of the Fourth Congress of the International Courtly Literature Society (Toronto, 1983), ed. G. S. Burgess and R. A. Taylor, Cambridge, D. S. Brewer, 1985, p. 79-89.

${ }^{21}$ The best description of the manuscript is in Hermann Julius Hermann, Die illuminierten Handschriften und Inkunabeln der Nationalbibliothek in Wien. VII : Die westeuropäischen Handschriften und Inkunabeln der Gotik und der Renaissance mit Ausnahme der niederländischen Handschriften. 2: englische und französische Handschriften, Leipzig, Hiersemann, 1936, p. 43-47. See J. Barrois, Bibliothèque protypographique ou librairies des fils du roi Jean, Charles V, Jean de Berri, Philippe de Bourgogne et les siens, Paris, Treuttel et Würtz, 1830, 1373, no. 140, and 1487, no. 1957.

22 Raoul de Houdenc, Sämtliche Werke, I: Meraugis von Portlesguez, ed. Mathias Friedwagner, Halle:, Niemeyer, 1897 ; line drawings of the miniatures are reproduced by H. Michelant, Meraugis de Portlesguez, roman de la Table Ronde, Paris, Tross, 1869. See also my «Mise en texte and mise en image : Meraugis de Portlesguez in Vienna, ÖNB 2599 », in 'Por le soie amisté' : Essays in Honor of Norris J. Lacy, ed. Keith Busby and Catherine 
thereby giving immediate notice of a strong authorial presence. This is underlined by the historiated initial « $Q$ » of the opening line, "Qui de rimoier s'entremet» (fol. $1 \mathrm{ra}$ ), which shows a seated male figure reading from a book on a lectern, his indexfinger raised in a didactic gesture. The romance of Meraugis de Portlesguez is thus represented in the manuscript itself as both text and performance, a double mise-enabime. Such evidence from manuscripts supports the textual evidence for authority and undercuts tendences to ignore authorial intention and personality. Even divorced from other texts in a single-item codex, a romance reaches out to the traditions on which it draws, notably the romances of Chrétien de Troyes.

The rest of the manuscript is decorated with alternating gold-pink and goldblue painted capitals, and illustrated with seventeen framed miniatures (ca. $3.5 \mathrm{~cm} \mathrm{x}$ $7 \mathrm{~cm}$ ) with diapered backgrounds; there are no rubrics. Located at more or less regular intervals throughout the text, the miniatures are largely centered around the figure of Meraugis. Many of these show his struggles against various opponents : Gorvain Cadrut (fol. 5vb, fol. 38vb ), Laquis de Lampagrés (fol. 12ra), the Outredoté (fol. 29rb, fol. 30ra), Calogrenant (fol. 35rb); others illustrate the romance's most memorable scenes : the Esplumeor Merlin (fol. 17vb), the Garden of Carols (fol. 24rb), Meraugis cutting off the Outredoté's hand and subsequent faint (fol. 30rb, fol. 30va), the arrival of Amice (fol. 33rb), and the hero's reunion with Lidoine (fol. 37rb). It is precisely this type of dramatic moment, often with supernatural connections, that is also chosen for illustration in other texts. ${ }^{23}$ The sequence of miniatures also appears to offer a fair reflection of the narrative, and certainly enough to remind a reader of the basic plot and main concerns of the romance. The combat between Meraugis and Gorvain (fol. 5vb) establishes the rivalry between cortoisie and beauté, and the kiss between Lidoine and Meraugis (fol. 7rb) illustrates the decision in the latter's favour; the love interest is further illustrated by the reunion of Meraugis and Lidoine (fol. 37rb) and the final defeat of Gorvain (fol. 38va).

The miniatures also reflect a female-dominated narrative : the rivalry between Meraugis and Gorvain for the love of Lidoine; the decision by the court of ladies ; Lidoine's testing of Meraugis during his «probationary year»; the female prophets of the Esplumeor Merlin; the imprisonment of Gauvain and Meraugis by the lady of the island; the detention of the Outredoté and Meraugis in the carolling garden populated only by maidens. A particularly interesting feature of many of the miniatures is the representation of what might be called the «female gaze»: the first miniature (fol. 2vb) shows women looking down from a platform, left, on the tournament at Lindesores ; a group of women look on as Lidoine separates Meraugis and Gorvain (fol. 5vb) ; eleven maidens look on as another talks to Meraugis at the Esplumeor Merlin (fol. 17vb) ; three women look on as Gauvain meets Meraugis on the island (fol. 20va); female observers are also visible in the miniatures on fol.

M. Jones, Amsterdam, Rodopi, 2000, p. 96-116, with reproductions of all of Michelant's linedrawings.

${ }^{23}$ See my «The Illustrated Manuscripts of Chrétien's Perceval», Zeitschrift für französische Sprache und Literatur, 98, 1988, p. 41-52, rpt. in Les manuscrits de Chrétien de Troyes, I, p. 351-63 and «Text, Miniature, and Rubric in the Manuscripts of the Perceval Continuations », ibid., p. 365-76. 
$24 \mathrm{rb}, 33 \mathrm{rb}$, and $37 \mathrm{rb}$. This representation of the female gaze reflects not only observation by women of events in the text but is also indicative of the female element in the intended audience or readership of ÖNB 2599 : the onlookers watch events unfold as the audience listens to them being recited or as the reader reads. And the performance is mediated, perhaps even controlled, by the authorial presence of Raoul in the historiated initial of 1.1 .

Another remarkable feature of the miniatures in ÖNB 2599 is their detail. For example, in the miniature on fol. $2 \mathrm{vb}$ depicting the tournament at Lindesores, one woman holds a lance with a circular banner with a red heart on it, and from the heart grow two flowers ; this same motif is on the arms of a knight, presumably Meraugis, fighting on the left. What we may have here is a female blazon, supplementing the female gaze, the heart representing Lidoine, and the two flowers, her rivals. On fol. 30ra, depicting the combat between Meraugis and the Outredoté, the latter's shield is shown exactly as described in 1.4453 («Le roge escu au serpent noir»), and on fol. $35 \mathrm{rb}$, Meraugis bears a white shield with the letter « $\mathrm{W} »$ on it in red; the text refers to him several times in this episode as «le blanc chevalier" (1. 5386), "cil blans chevaliers » (1. 5396), and «cil au blanc escu» (1. 5407). This kind of symbolic detail reinforces the quasi-allegorical mode of the romance and is perfectly consonant with the kind of reading of Meraugis de Portlesguez generated by a synthesis of the merveilleux and the moralistic. The artist of this attractive manuscript, or possibly a planner who may have given instructions as to what to depict, had clearly read the romance with a considerable degree of care.

Vatican City, BAV, Reg. Lat. 1725 (s. $13^{\text {ex. }}$ ) dates from the end of the thirteenth century and contains Chrétien's Lancelot (fol. $1 \mathrm{r}^{\circ}-34 \mathrm{r}^{\circ} \mathrm{b}$, starting at 1. 861), Yvain (fol. $34 \mathrm{v}^{\circ} \mathrm{a}-68 \mathrm{r}^{\circ} \mathrm{b}$ ), Jean Renart's Guillaume de Dole (fol. $68 \mathrm{v}^{\circ} \mathrm{a}-98 \mathrm{v}^{\circ} \mathrm{a}$ ), and Meraugis (fol. $98 \mathrm{v}^{\circ} \mathrm{b}-130 \mathrm{v}^{\circ} \mathrm{b}$ ). An old foliotation indicates that there are forty-eight folios missing at the beginning, but the present contents are in their original order. A number of common denominators link the four romances. It is possible, for example, to view Reg. Lat. 1725 as an anthology exploring different aspects of male companionship: of Lancelot and Gauvain, Yvain and Gauvain, Conrad and Guillaume, Meraugis and Gorvain. The codex could also be seen as intended for a female audience or readership, given that most of the adventures in all four romances are ultimately initiated by women and all have a woman at their centre, despite their male heroes. These two views are not contradictory, and male and female users of the manuscript would doubtless respond in their individual ways. The compiler may well have had in mind to offer something of interest to users of both genders. Guillaume de Dole and Meraugis de Portlesguez explore two different directions of post-Chrétien verse romance, suggesting that the audience for romance at this time was interested not only in content but also in the aesthetics of the genre and its evolution.

As in the Nottingham manuscript, the figure of the jongleur seems to bind the texts together in Reg. Lat. 1725. Here, the figure of Juglet in Guillaume de Dole illustrates the power of poetry to mirror experience, to alter men's lives, and to save empires. For all its apparent realism, Guillaume de Dole is a thoroughly literary romance, in which lyric insertion functions as an apparently everyday means of expression, and in which the character's behaviour is evaluated largely by comparison with figures from contemporary romance and epic. Its position between 
the Lancelot-Yvain pair and Meraugis de Portlesguez enables it to function both as a commentary on the work of Chrétien and as a prospectus for Raoul's romance.

Rhetoric is at the core of Guillaume de Dole in that Conrad falls in love with Lienor on the basis of Juglet's description of a woman in a tale he is telling. Although the description is of a fictional character in a tale destined to remain unfinished, Conrad clearly transfers it to Lienor as soon as her name is mentioned by Juglet (11. $621 \mathrm{ff}.) .^{24}$ This interesting variation on the " amour de loin » theme lays the basis for the constant interplay between "fact» and fiction in Guillaume de Dole, and as Lienor becomes endowed with the attributes of Juglet's portrait, so her brother Guillaume's beauty is explained by positing his provenance in literature (ll. 1431-32). The melding of reality and literature is eloquent testimony to the power of poetry and the importance of the jongleur as mediator. Guillaume de Dole is furthermore generally replete with allusions to contemporary narrative : Le roman de Renart (11. 444, 5421), Perceval (11. 1747, 2880), Roncevaux (1. 1748), Charlemagne (1. 1756), the fabliaux (1. 1765), Vivien (1. 2304), Graelent (1. 2546), Roland (1. 2755), Alexander (11. 2880, 5320), Keu (1l. 3160, 3164), Berte aux grands pieds, Aude, and Olivier (11. 4509-12), Arthur (11. 4618, 4681), the story of Troy (11. 533251), Tristan and Iseut (11. 5507), and Lanval (1. 5511). Many of these allusions are straightforward comparisons, where a character in said to be braver or more beautiful than another, but others have a more structural function, as I suggested was the case with some of the references in Mi. LM. 6.

The post-prandial entertainment offered to Guillaume after his first meeting with Conrad (11. 1740-65) includes Arthurian romance, chansons de geste, lyric poetry and fabliaux (the latter two genres performed by Juglet), and creates a strong impression of the unity of the jongleur's repertoire. Clearly, the scene is not to be taken literally because of time constraints, but is surely intended as an idealistic presentation of the kind of works to which Guillaume and Conrad might have listened. The attribution to Conrad's seneschal of Keu's arms (11. 3159-64) prepares us for his despicable behaviour and links the romance to the other three items in the manuscript, in all of which Arthur's seneschal behaves shabbily. Something similar is true of the court's reaction to Lienor's arrival :

Tex puceles soelent venir ça en arrier, por esbaudir, a la court le bon roi Artu.

[...]

Puis cele heure que Dex fu nez, neïs au tens le roi Artur, ne sai se c'est par vostre eür, n'avint ausi bele aventure, ce cuit, de nule creature com il a la fors avenu. (11. 4617-19;4680-85)

${ }^{24}$ Jean Renart, Le roman de la rose ou de Guillaume de Dole, ed. F. Lecoy, Paris, Champion, 1962. 
This draws Conrad's court into the orbit of Arthur's, turning it into a new Carduel/Camelot. The comparison is therefore also pregnant with political implications for Milon de Nanteuil, to whom Guillaume de Dole is dedicated. If the possible descendancy of Milon through a sister of the German emperor Conrad III, and Jean Renart's possible relationship with nobility from Limburg or Brabant might explain the setting of the romance in Germanic regions rather than in France, ${ }^{25}$ its net effect in the context is to integrate Arthur's Britain into the Empire along with the Carolingian domains. Lienor's coronation robe, with its depiction of the story of Helen of Troy (11. 5324-51), assimilates the matter of antiquity.

In Reg. Lat. 1725, the performance of lyrics serves to bind Guillaume de Dole with Meraugis de Portlesguez. One of the central scenes in the latter romance is that in the carolling garden (11. $3662 \mathrm{ff}$.). Towards the beginning of Guillaume de Dole, Conrad and his companions disport themselves in a carol with some maidens (11. 507-10) This is only one of many references to the «carole» (cf. also 11. 516, $1569,2364,2372,5200$, and 5428) and to lyrics being performed by women (e.g., 11 . 1155 ff., 1841 ff., 4566 ff., 4653 ff.). The episode cited is from Conrad's carefree, and arguably unproductive, period before he falls in love with Lïenor; although lyric poetry often fulfils its human and social potential in a proper amorous context in Guillaume de Dole, when bereft of purpose, it is empty and meaningless. Likewise, the unfortunate knights who enter the carolling garden in Meraugis are destined to remain with rhyme, but without reason, until liberated by the next comer.

Meriadeuc or Le chevalier aux deux épées (ca. 1240) is preserved only in Paris, BnF, fr. 12603 (s. $13^{\text {ex. }}$ s. $-14^{\text {inc. }}$ ), an anthology manuscript from the end of the thirteenth century, probably produced in Arras. ${ }^{26}$ Fr. 12603 also contains, in order, Chrétien's Yvain (fol. 1r-71r), Le roman d'Enéas (fol. 111r-144v), Wace's Brut (fol. 144v-155v), Adenet de Roi's Les enfances Ogier (fol. 156r-202v), Fierabras (fol. 203r-238r), a number of fabliaux and other short works (fol. 239r-278v; 301r302v), and Marie de France's Ysopet (fol. 279r-301r). Like Les merveilles de Rigomer in Chantilly 472, Le chevalier aux deux épées is a long romance at the head of a large manuscript (fol. 1-71rb), although its function is somewhat different. A full commentary on this manuscript is out of the question, but it seems to consist of two units, one composed of romances and epics (fol. 1-238), and the other of short tales and Marie's Ysopet (fol. 239-302) ; both units were likely produced in the same workshop.

In the case of fr. 12603, there is clear evidence of a scribal or compilatorial attempt to conjoin works, as in the links between Yvain and the Eneas, and between the Eneas and the Brut. In the first case (f. 110ra), there is a scribal explicit that seems to look forward to the identification of further texts for inclusion in the codex. In the second instance (fol. 144vb), the prologue of the Brut is omitted and its text

\footnotetext{
${ }^{25}$ Lecoy, ed. cit., p. xiii-xv. See now John W. Baldwin, Aristocratic Life in Medieval France: The Romances of Jean Renart and Gerbert de Montreuil, 1190-1230, Baltimore, The Johns Hopkins Univ. Press, 2000, p. 32-58.

${ }^{26}$ See Terry Nixon's description in Les manuscrits de Chretien de Troyes, II, p. 69-70; the text has beeen edited by Wendelin Foerster, Li chevaliers as deus espees, Halle, Niemeyer, 1877. Cf also Richard Trachsler, «Le recueil Paris, BnF fr. 12603 », Cultura Neolatina, 54, 1994, 189-211.
} 
grafted seamlessly to the Eneas as if it were a continuation. The scribe omits Eneas, 11. 10130-end, and adds :

Aprés gaires ne demora,

Li rois du siecle trespassa,

Et la terre ot toute Eneas,

S'ot a moullier Lavinias.

Puisqu'Eneas Lavine ot prise,

Et la terre toute conquise...

where the last two lines are Brut, 11. 67-68, the first two lines of the narrative proper.

One of the structuring elements of Le chevalier aux deux épées is the opposition of two Brien's, Brien des Illes and Brien de la Gastine, to the families of Gauvain and Meriadeuc, respectively. The assaults on these two families constitute an attack on the very essence of Arthurian romance. Insofar as he is Arthur's heir apparent, Gauvain is the king's surrogate, and his death would be the death of the realm and, by extension, its ability to generate tales. Meriadeuc is the son of one Bleheri, who appears elsewhere in romance as a renowned teller of tales, and celebrated in Giraldus Cambresis as ille famosus fabulator Bledhericus (whom Pierre Gallais identified as the Welsh nobleman Bleddri ap Cadivor) ${ }^{27}$ Meriadeuc's Welsh name and descent again take us back to the Celtic origins of Arthurian romance and its very transmission on the continent. Less obviously structured perhaps than Chantilly 472, fr. 12603 nevertheless reverses the usual translatio studii by placing the Celtic world at the head of the compilation, underlining at least the worthiness of Arthurian romance to stand alongside the matière de Rome, here represented by the Eneas. The death of Meriadeuc would entail the end of storytelling; Meriadeuc, however, defeats Brien de la Gastine as Gauvain does Brien des Illes, thereby ensuring both the continued creation of narrative materia and its means of performance. This is symbolized by the depiction of Arthur's conception and reign on the coronation robe of the Queen of Caradigan (11. 1216997), elevating the matière de Bretagne to the same status enjoyed by that of the ancient world (cf. Martianus Capella on Enide's coronation robe and the story of Helen on that of Lïenor in Guillaume de Dole). It is no coincidence either that Yvain fails to remove the sword from Lore's waist in Le chevalier aux deux épées (ll. 1350-78), for failure destines him to remain unmarried and paves the way for his relationship with Laudine in Yvain, the next romance in the codex.

In Paris, BnF, fr. 2168 (s. 13 ${ }^{2 / 2}$ ), L'âtre périlleux heads the manuscript (fol. 145r) and is followed by Le vilain de Farbu, a "filler" at the end of the quire (fol. $45 \mathrm{v}$ ). The lacuna at the beginning of Yonec (fol. 47r) makes the structure of the codex difficult to analyze, but there is clearly organization in the sequence of Lais (fol. 47-70) followed by Aucassin et Nicolette (fol. 70rb-80vb), Raoul de Houdenc's Le songe d'Enfer (fol. 80vb-84va), La bataille de Quaresme et de Charnage (fol. $84 \mathrm{va}-88 \mathrm{rb}$ ), and the fabliau of Le secretan moine (fol. 88rb-91va). Aucassin's

\footnotetext{
${ }^{27}$ See Pierre Gallais, « Bleheri, la cour de Poitiers et la transmission des récits arthuriens sur le continent», in Moyen Âge et littérature comparée. Actes du VII congrès national de littérature comparée, Paris, Didier, 1967, p. 47-79.
} 
blasphemous desire to go to Hell rather than Heaven is troped in Le songe d'Enfer, and the food-fight is troped in Quaresme et Charnage; in Le secretan moine, the dead sacristan is propped up on horseback in a parodic joust. I cannot explore this comic interplay in the detail it deserves here, but suffice to say that it may invite reflection on the burlesque side of L'atre périlleux with which it opens at the same time as it draws out chivalric elements in the non-romance texts, underlining once again the unity of the Old French literary corpus and the danger of too rigid a demarcation of genres. In addition to fr. 2168 and Chantilly 472, L'âtre périlleux also appears in BnF, fr. 1433 (possibly Tournai; s. $14^{1 / 4}$ ), where it precedes Chrétien's Yvain. In this context, L'âtre périlleux functions in word and image as a substitute for Lancelot in Chrétien's own pairing of the latter with Yvain (recoginzed by the planner of Princeton, UL, Garrett 125), in both of which romances aspersions had been cast on Gauvain's comprehension of the relationship between love and chivalry. It is more than likely that medieval readers of fr. 1433 would have been aware of the Lancelot-Yvain pair and would have responded to the virtual intertextuality of Lancelot and L'âtre périlleux as well as the more tangible interplay between the two items actually contained in the codex.

This survey of the manuscripts of post-Chrétien, epigonal, verse romances has shown, I hope, the kind of light that can be shed on their reception by examination of their manuscript context. While such study may not tell us more about their meaning for primary audiences than can be gained from reading wellprepared modern critical editions, it provides crucial evidence to supplement that gained from purely textual sources. In particular, it restores the place of such romances in the larger system of medieval French verse narratives, elucidating their relationship with romances of antiquity, non-Arthurian courtly romance, chansons de geste, and varieties of short tales, including Breton lais and scurrilous fabliaux.

Keith Busby

University of Wisconsin-Madison 